\title{
Predicting Gaseous Pollution of Sintered Brick Preparation from Yellow Phosphorus Slag
}

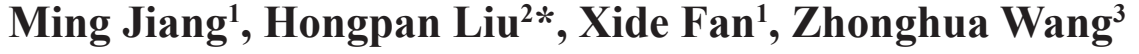 \\ ${ }^{1}$ College of Resources and Environment, Yunnan Agricultural University, Kunming, China \\ ${ }^{2}$ College of Materials and Chemical Engineering, Chongqing University of Arts and Sciences, Chongqing, China \\ ${ }^{3}$ Faculty of Environmental Science and Engineering, Kunming University of Science and Technology, Kunming, China
}

Received: 6 January 2018

Accepted: 11 April 2018

\begin{abstract}
To investigate secondary pollution issued during the preparation of sintered brick from waterquenched yellow phosphorus slag, the composition of slag was experimentally measured in this study. The thermal conversion process and gas phase products associated with S-, P-, F-, and As-containing species present in the heating system were theoretically calculated by means of thermochemical software FactSage 7.0 and databases. The results showed that $\mathrm{F}$ and $\mathrm{As}$ were released at $700^{\circ} \mathrm{C}$ and the gaseous products contained $\mathrm{AsF}_{3}$. Also, large amounts of $\mathrm{F}$ remained in solid $\mathrm{CaF}_{2}$ and $\mathrm{Ca}_{10}\left(\mathrm{PO}_{4}\right)_{6} \mathrm{~F}_{2}$. At a calcination temperature of $900^{\circ} \mathrm{C}$, all As was transferred into gaseous $\mathrm{AsF}_{3}$ and $\mathrm{S}$ started to convert into gaseous $\mathrm{SO}_{2}$ and $\mathrm{SO}_{3}$. Other data suggested that the released amounts of $\mathrm{SO}_{2}$ and $\mathrm{SO}_{3}$ increased as calcination temperature rose. At calcination temperatures ranging from $100-1000^{\circ} \mathrm{C}$, all $\mathrm{P}$ existed as solid $\mathrm{Ca}_{10}\left(\mathrm{PO}_{4}\right)_{6} \mathrm{~F}_{2}$. These findings indicated that low calcination temperatures were beneficial for reducing released harmful gases during the production of sintered brick.
\end{abstract}

Keywords: yellow phosphorus slag, sintered brick, factsage, gaseous pollution

\section{Introduction}

Yellow phosphorus slag is a molten byproduct formed during yellow phosphorus production, where the production of one ton of yellow phosphorus releases about 8-10 tons of yellow phosphorus slag [1]. To reduce the thermal pollution by natural cooling process of molten slag and prevent the formation of bulk slag that is difficult to transport and pretreat after natural cooling, molten slag is often rapidly cooled by water quenching, known as water-quenched phosphorus slag. As slag is stacked and dried for long periods, large amounts of land

*e-mail: sclhpkm@126.com occupation and environmental pollution are produced. Yellow phosphorus slag is used in many fields, including the preparation of building materials like sintered brick [2], cement [3], and recycled aggregate concrete [4]. It is also employed in inorganic fillers, such as spherical calcium carbonate [5], calcium carbonate whisker [6], and precipitated silica [7]. Decorative materials [8] like porous glass [9], glass-ceramics [10], and ceramics timber [11] also use yellow phosphorus slag. However, the most prominent field of application is still in the production of building materials.

Sintered brick is an important building material issued from industrial solid waste. Yellow phosphorus slag might be employed as partial substitutes for clay in sintered brick manufacturing. This recycling process 
does not only increase the strength of the bricks but also decreases the sintering temperature and reduces energy consumption [12]. During the production process of sintered brick, the calcination process is considered as an essential step. However, toxic and harmful elements present in yellow phosphorus slag will migrate and transfer into the gas phase during calcination. In particular, the use of large amounts of phosphorus slag as material for sintered brick releases several toxic gaseous pollutants, which do not only pollute the surrounding air but also endanger human health. Therefore, the potential environmental hazards issued from building materials during calcination of industrial solid waste must be resolved [13], and the release characteristics of gaseous pollutants should be predicted.

Thermochemical software and databases often help in understanding the chemical thermodynamic processes of materials at high temperatures. The related calculations, simulations, analyses, and predictions should improve the efficiency of research. FactSage $[14,15]$ is a well-known software and database package for chemical thermodynamics. FactSage is applied in materials sciences, environmental sciences, corrosion, metallurgy, ceramics, and combustion, among others. Recently, FactSage was shown to be advantageous for calculating and simulating the release characteristics of harmful components issued from materials at high temperatures. For instance, FactSage was utilized to predict the chemical species of trace elements $(\mathrm{Pb}$ and $\mathrm{Se})$ released during coal gasification [16], as well as to simulate and predict gaseous pollution during yellow phosphorus production [17]. The software is also utilized to investigate elements ( $\mathrm{S}$ and $\mathrm{Ca}$ ) transformation and reaction model during phosphogypsum decomposition [18], as well as to predict the release characteristics of gaseous alkali metals derived from biomass and coal co-firing [19]. FactSage also proved its usefulness for simulating the migration and transformation of $\mathrm{Ca}$, $\mathrm{Al}$, and $\mathrm{Si}$ during the preparation of glass-ceramics calcination [20]. However, to the best of our knowledge, no reports dealing with gaseous pollution prediction of sintered brick preparation from yellow phosphorus slag have so far been published.

In this work, the release characteristics of S, P, F, As, and related chemical reactions during the preparation of sintered brick were explored by component analysis of water-quenched phosphorus slag combined with published raw material ratio of sintered brick production [12] and FactSage 7.0-based calculations. Particular attention was paid to predict and obtain the molecular state and equilibrium distribution of S, P, F, and As in the gaseous, solid, and slag phases.

\section{Experimental}

\section{Materials}

Water-quenched yellow phosphorus slag (Yuxi, Yunnan, China) was crushed and dried at $100^{\circ} \mathrm{C}$ for $24 \mathrm{~h}$, and then sieved to $200 \mathrm{mesh}(74 \mu \mathrm{m})$.

\section{Analytical Methods}

The contents of S, P, F, and As in the slag were respectively analyzed using the following methods: sodium carbonate-zinc oxide semi-molten gravimetric, phosphorus molybdenum blue colorimetric, fluoride ion selective electrode, and atomic fluorescence spectrometry (AFS-2201, Beijing Haiguang Instrument, China). The remaining components of the slag were measured by x-ray fluorescence spectrometry (ZSX100e, Rigaku, Japan). The composition of the slag is listed in Table 1.

\section{Raw Material Formulas and Analysis}

The preparation process of sintered brick from yellow phosphorus slag was previously described in the literature [12]. The preparation temperature of sintered brick was maintained at $1000^{\circ} \mathrm{C}$, and the formulas of raw materials are compiled in Table 2. It can be seen that the main components of the sintered brick were $\mathrm{CaO}$, $\mathrm{Al}_{2} \mathrm{O}_{3}$, and $\mathrm{SiO}_{2}$, with respective percentages of $20.55 \%$, $13.84 \%$, and $47.46 \%$ (Table 2). After normalization and keeping the contents of other components constant, the percentages of $\mathrm{CaO}, \mathrm{Al}_{2} \mathrm{O}_{3}$, and $\mathrm{SiO}_{2}$ increased to $25.11 \%, 16.91 \%$, and $57.98 \%$, respectively. The content of $\mathrm{CaO}$ in the phosphorus slag (Table 1) was higher than that of the sintered brick (Table 2). To obtain $\mathrm{CaO}$ $\mathrm{Al}_{2} \mathrm{O}_{3}-\mathrm{SiO}_{2}$ (CAS) ternary sintered brick, the addition of suitable amounts of $\mathrm{Al}_{2} \mathrm{O}_{3}$ and $\mathrm{SiO}_{2}$ to phosphorus slag was required. This was aimed at obtaining the same contents of $\mathrm{SiO}_{2}, \mathrm{CaO}$, and $\mathrm{Al}_{2} \mathrm{O}_{3}$ in the sintered brick after normalization.

Based on the above considerations, $\mathrm{Al}_{2} \mathrm{O}_{3}$ $(29.21 \mathrm{~g})$ and $\mathrm{SiO}_{2}(72.40 \mathrm{~g})$ were added to the raw material when $100 \mathrm{~g}$ of water-quenched yellow

Table 1. Composition of water-quenched yellow phosphorus slag.

\begin{tabular}{|l|c|c|c|c|c|c|c|}
\hline Composition & $\mathrm{CaO}$ & $\mathrm{Al}_{2} \mathrm{O}_{3}$ & $\mathrm{SiO}_{2}$ & $\mathrm{~S}$ & $\mathrm{P}$ & $\mathrm{F}$ & $\mathrm{As}$ \\
\hline Content/wt\% & 48.70 & 3.59 & 40.05 & $9.68 \times 10^{-2}$ & 0.58 & 3.06 & $1.93 \times 10^{-4}$ \\
\hline Composition & $\mathrm{Na}_{2} \mathrm{O}$ & $\mathrm{MgO}$ & $\mathrm{K}_{2} \mathrm{O}$ & $\mathrm{TiO}_{2}$ & $\mathrm{Fe}_{2} \mathrm{O}_{3}$ & $\mathrm{ZnO}$ & $\mathrm{SrO}$ \\
\hline Content/wt $\%$ & 0.34 & 0.86 & 0.94 & 0.41 & 0.93 & 0.11 & 0.12 \\
\hline
\end{tabular}

Note: The contents of the other components were all $0.2 \%$ 
Table 2. The composition of raw materials in the sintered brick prepared from yellow phosphorus slag (wt $\%$ ).

\begin{tabular}{|c|c|c|c|c|c|c|c|}
\hline Raw materials & $\mathrm{CaO}$ & $\mathrm{Al}_{2} \mathrm{O}_{3}$ & $\mathrm{SiO}_{2}$ & $\mathrm{Fe}_{2} \mathrm{O}_{3}$ & $\mathrm{MgO}$ & $\mathrm{P}_{2} \mathrm{O}_{5}$ & Loss \\
\hline Clay & 0.89 & 19.73 & 54.77 & 9.56 & 2.07 & - & 9.66 \\
\hline $\begin{array}{c}\text { Phosphorus } \\
\text { slag }\end{array}$ & 49.06 & 4.97 & 38.07 & 0.69 & 1.00 & 2.32 & - \\
\hline Fly ash & 4.77 & 19.89 & 48.51 & 9.84 & 0.47 & - & 12.54 \\
\hline Total & 20.55 & 13.84 & 47.46 & 6.04 & 1.48 & 0.93 & 6.08 \\
\hline
\end{tabular}

Note: clay:phosphorus slag:fly ash mass ratio $=5: 4: 1$

phosphorus slag was used to prepare $\mathrm{CaO}-\mathrm{Al}_{2} \mathrm{O}_{3}-\mathrm{SiO}_{2}$ sintered brick. The equilibrium amounts and distribution of S, P, F, and As were calculated using the Equilib module and FactPs databases [15]. The equilibrium gaseous products were considered as ideal gases, and molten slag as real solution [17]. Before simulations, the calculation parameters were set as follows: 1) the reactants in sintered brick formulations were calculated as input participant reactants as listed in Table 3,2) the temperature was maintained in the range of $100-1000^{\circ} \mathrm{C}$ with a step length of $100^{\circ} \mathrm{C}$, and 3) atmospheric pressure was controlled at $101325 \mathrm{~Pa}$.

\section{Results and Discussion}

\section{Prediction of Equilibrium Amounts of Gaseous Pollutants}

Fig. 1 shows the equilibrium amounts of S-, P-, F-, and the As-containing gas phase products at different

Table 3. Composition of the $\mathrm{CaO}-\mathrm{Al}_{2} \mathrm{O}_{3}-\mathrm{SiO}_{2}$ sintered brick.

\begin{tabular}{|c|c|c|c|}
\hline Composition & $\begin{array}{c}\text { Phosphorus } \\
\text { slag/wt } \%\end{array}$ & Additive/g & $\begin{array}{c}\text { Sintered } \\
\text { brick/g }\end{array}$ \\
\hline $\mathrm{CaO}$ & 48.70 & & 48.70 \\
\hline $\mathrm{Al}_{2} \mathrm{O}_{3}$ & 3.59 & 29.21 & 32.80 \\
\hline $\mathrm{SiO}_{2}$ & 40.05 & 72.40 & 112.45 \\
\hline $\mathrm{S}$ & $9.68 \times 10^{-2}$ & & $9.68 \times 10^{-2}$ \\
\hline $\mathrm{P}$ & 0.58 & & 0.58 \\
\hline $\mathrm{F}$ & 3.06 & & 3.06 \\
\hline $\mathrm{As}$ & $1.93 \times 10^{-4}$ & & $1.93 \times 10^{-4}$ \\
\hline $\mathrm{Na}_{2} \mathrm{O}$ & 0.34 & & 0.34 \\
\hline $\mathrm{MgO}^{2}$ & 0.86 & & 0.86 \\
\hline $\mathrm{K}_{2} \mathrm{O}$ & 0.94 & & 0.94 \\
\hline $\mathrm{TiO}_{2}$ & 0.41 & & 0.41 \\
\hline $\mathrm{Fe}_{2} \mathrm{O}_{3}$ & 0.93 & & 0.93 \\
\hline $\mathrm{ZnO}$ & 0.11 & & 0.11 \\
\hline $\mathrm{SrO}$ & 0.12 & & 0.12 \\
\hline
\end{tabular}

temperatures. The equilibrium amounts increased as temperature rose. On the other hand, the equilibrium amounts of P-containing gaseous pollutants were very low in the entire temperature range from 100 to $1000^{\circ} \mathrm{C}$, indicating the presence of phosphorus in the solid phase or liquid slag phase. At temperatures above $900^{\circ} \mathrm{C}$, the equilibrium amounts of $\mathrm{F}$ and As containing gaseous pollutants gradually stabilized. The amount of $\mathrm{S}$ was higher than those of $\mathrm{F}$ and $\mathrm{As}$ at temperatures exceeding $950^{\circ} \mathrm{C}$. This suggested that elevated temperatures $\left(950-1000^{\circ} \mathrm{C}\right)$ accelerated the volatilization of $\mathrm{S}$ during the preparation of sintered brick.

\section{Migration and Transformation of Sulfur}

The distribution of S-containing species in different phases during the heating process of prepared sintered brick from water-quenched yellow phosphorus slag is depicted in Fig. 2. The $\mathrm{S}$ state of yellow phosphorus slag existed as $\mathrm{CaSO}_{4}(61.64 \%)$ and $\mathrm{SrSO}_{4}(38.36 \%)$ under $800^{\circ} \mathrm{C}$. At $900^{\circ} \mathrm{C}$, the $\mathrm{S}$-containing gaseous pollutants $\left(\mathrm{SO}_{2}\right.$ and $\left.\mathrm{SO}_{3}\right)$ started to form, and the released amounts increased as temperature rose. From $900^{\circ} \mathrm{C}$ to $1000^{\circ} \mathrm{C}$, the released amounts increased from $0.04 \%$ to $0.85 \%$ for $\mathrm{SO}_{2}$ and from $0.01 \%$ to $0.13 \%$ for $\mathrm{SO}_{3}$. Meanwhile, the content of $\mathrm{CaSO}_{4}$ declined from $61.59 \%$ to $60.66 \%$. However, the content of $\mathrm{SrSO}_{4}$ was still maintained at

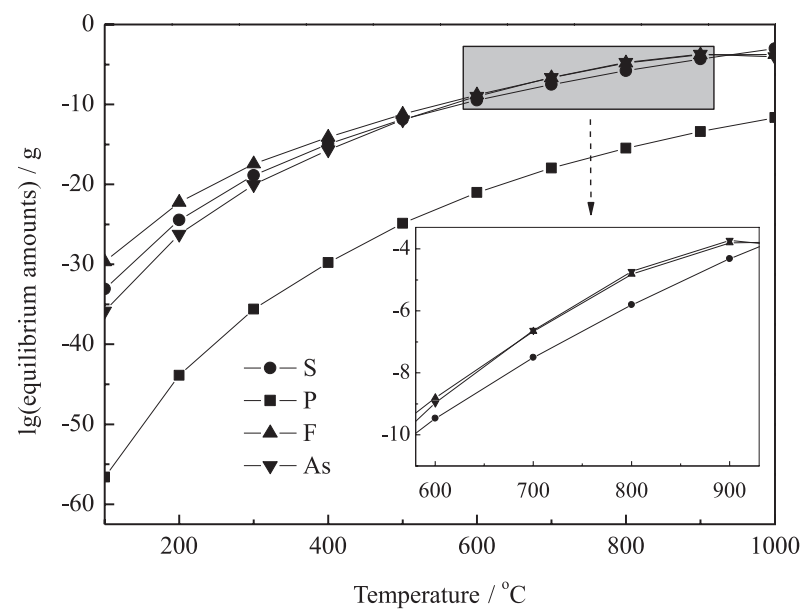

Fig. 1. Equilibrium amounts of harmful gases released during the preparation of sintered brick as a function of temperature. 


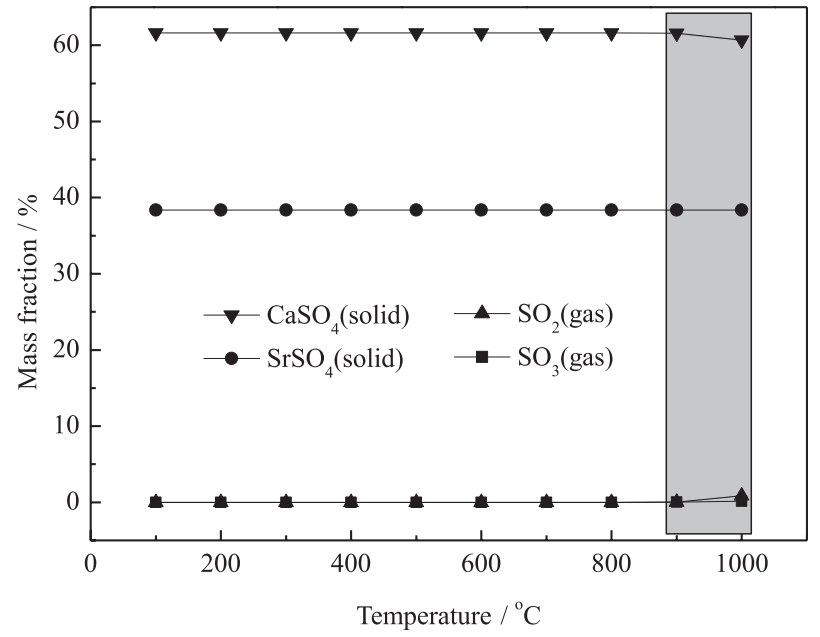

Fig. 2. Distribution of sulfur products in different phases during the heating process.

$38.36 \%$, demonstrating the formation of gas phase $\mathrm{SO}_{2}$ and $\mathrm{SO}_{3}$ during the thermal decomposition of $\mathrm{CaSO}_{4}$ at $T>900^{\circ} \mathrm{C}$.

A number of studies determined the initial decomposition temperature of pure $\mathrm{CaSO}_{4}$ solid to range from $1200-1250^{\circ} \mathrm{C}$ [21-22]. Here, $\mathrm{CaSO}_{4}$ decomposed at $900^{\circ} \mathrm{C}$ for two reasons. First, the water-quenched yellow phosphorus slag used as a material for preparing sintered brick contained mainly $\mathrm{Ca}, \mathrm{Si}$, and $\mathrm{Al}$. Thus, the $\mathrm{SiO}_{2}$ and $\mathrm{Al}_{2} \mathrm{O}_{3}$ in phosphorus slag may react with active $\mathrm{CaO}$ issued from decomposition products of $\mathrm{CaSO}_{4}$ to form silicate minerals $\left(\mathrm{Ca}_{2} \mathrm{SiO}_{4}, \mathrm{CaSiO}_{3}\right)$ and aluminate minerals $\left(\mathrm{CaAl}_{2} \mathrm{O}_{4}\right)$ at high temperatures [22]. These solid-phase reactions accelerated the decomposition of $\mathrm{CaSO}_{4}$, according to Eqs. (1)-(4). Second, $\mathrm{CaSO}_{4}$ could react with $\mathrm{SiO}_{2}$ or $\mathrm{Al}_{2} \mathrm{O}_{3}$ at high temperatures (Eqs. (5) and (6)), reducing the thermal stability of $\mathrm{CaSO}_{4}$. The above two reasons showed that $\mathrm{SiO}_{2}$ and $\mathrm{Al}_{2} \mathrm{O}_{3}$ in phosphorus slag accelerated $\mathrm{CaSO}_{4}$ decomposition and reduced the initial decomposition temperature of $\mathrm{CaSO}_{4}$. The released $\mathrm{SO}_{2}$ and $\mathrm{O}_{2}$ from these solid-phase reactions could further be combined to form $\mathrm{SO}_{3}$ (Eq. (7)).

$$
\begin{gathered}
2 \mathrm{CaSO}_{4} \rightarrow 2 \mathrm{CaO}+2 \mathrm{SO}_{2}+\mathrm{O}_{2} \\
2 \mathrm{CaO}+\mathrm{SiO}_{2} \rightarrow \mathrm{Ca}_{2} \mathrm{SiO}_{4} \\
\mathrm{CaO}+\mathrm{SiO}_{2} \rightarrow \mathrm{CaSiO}_{3} \\
\mathrm{CaO}+\mathrm{Al}_{2} \mathrm{O}_{3} \rightarrow \mathrm{CaAl}_{2} \mathrm{O}_{4} \\
6 \mathrm{CaSO}_{4}+4 \mathrm{SiO}_{2} \rightarrow 2 \mathrm{CaSiO}_{3}+2 \mathrm{Ca}_{2} \mathrm{SiO}_{4}+6 \mathrm{SO}_{2}+3 \mathrm{O}_{2} \\
2 \mathrm{CaSO}_{4}+2 \mathrm{Al}_{2} \mathrm{O}_{3} \rightarrow 2 \mathrm{CaAl}_{2} \mathrm{O}_{4}+2 \mathrm{SO}_{2}+\mathrm{O}_{2} \\
2 \mathrm{SO}_{2}+\mathrm{O}_{2} \rightarrow 2 \mathrm{SO}_{3}
\end{gathered}
$$

\section{Migration and Transformation of Phosphorus}

Fig. 3 depicts the distribution of P-containing species in different phases during the heating process. The $\mathrm{P}$ state of yellow phosphorus slag existed as $\mathrm{Ca}_{10}\left(\mathrm{PO}_{4}\right)_{6} \mathrm{~F}_{2}$ $(100 \%)$ at temperatures from $100-1000^{\circ} \mathrm{C}$, with no released P-containing gaseous pollutants. $\mathrm{Ca}_{10}\left(\mathrm{PO}_{4}\right)_{6} \mathrm{~F}_{2}$ (Fluorapatite) is considered as the main chemical composition of phosphate rock, which is the most stable form of all calcium phosphates [23]. The initial decomposition temperature of $\mathrm{Ca}_{10}\left(\mathrm{PO}_{4}\right)_{6} \mathrm{~F}_{2}$ was higher than $1200^{\circ} \mathrm{C}$ [24]. Yang et al. [25] reported that the $\mathrm{Al}_{2} \mathrm{O}_{3}$ accelerated the decomposition rate of $\mathrm{Ca}_{10}\left(\mathrm{PO}_{4}\right)_{6} \mathrm{~F}_{2}$ but had little effect on the initial decomposition temperature of $\mathrm{Ca}_{10}\left(\mathrm{PO}_{4}\right)_{6} \mathrm{~F}_{2}$. Liu et al. [26] suggested that the melting point of $\mathrm{Ca}_{10}\left(\mathrm{PO}_{4}\right)_{6} \mathrm{~F}_{2}$ could properly be reduced by adding $\mathrm{SiO}_{2}$ into the reaction system, but the solid-phase reaction temperature was always maintained at $1450^{\circ} \mathrm{C}$. Therefore, silica $\left(\mathrm{SiO}_{2}\right)$ was mainly used as the flux of phosphate rock during production of yellow phosphorus using electric furnace-based processes. The solid-phase reaction is given by Eq. (8) [17]. According to Fig. 3, $\mathrm{Ca}_{10}\left(\mathrm{PO}_{4}\right)_{6} \mathrm{~F}_{2}$ present in phosphorus slag may be issued from the unreacted phosphate rock during the production of yellow phosphorus. The main components of slag $\left(\mathrm{Al}_{2} \mathrm{O}_{3}, \mathrm{SiO}_{2}\right)$ did not obviously affect the thermal decomposition of $\mathrm{Ca}_{10}\left(\mathrm{PO}_{4}\right)_{6} \mathrm{~F}_{2}$ when slag was used for the preparation of sintered brick. This restricted the formation of P-containing gaseous pollutants.

$$
\begin{gathered}
6 \mathrm{Ca}_{10}\left(\mathrm{PO}_{4}\right)_{6} \mathrm{~F}_{2}+90 \mathrm{C}+43 \mathrm{SiO}_{2} \stackrel{1400^{\circ} \mathrm{C}}{\longrightarrow} \\
18 \mathrm{P}_{2}+90 \mathrm{CO}+3 \mathrm{SiF}_{4}+20 \mathrm{Ca}_{3} \mathrm{Si}_{2} \mathrm{O}_{7}
\end{gathered}
$$

\section{Migration and Transformation of Fluorine}

F was ranked as the highest percentage of all four harmful elements in yellow phosphorus slag (Table 1). Therefore, the $F$ state of sintered brick preparation from phosphorus slag must further be examined. Fig. 4 illustrates the distribution of F-containing species in different phases during the heating process. The $\mathrm{F}$ state of phosphorus slag existed as solid phase $\mathrm{Ca}_{10}\left(\mathrm{PO}_{4}\right)_{6} \mathrm{~F}_{2}(3.88 \%)$ and $\mathrm{CaF}_{2}(96.12 \%)$ at temperatures ranging from $100-900^{\circ} \mathrm{C}$ (the existence of $\mathrm{Ca}_{10}\left(\mathrm{PO}_{4}\right)_{6} \mathrm{~F}_{2}$ in phosphorus slag was discussed in the previous section). The production of yellow phosphorus by means of an electric furnace at $1400^{\circ} \mathrm{C}$ may promote the occurrence of some by-reactions (Eqs. (9) and (10)) [27]. Excess $\mathrm{CaF}_{2}$ was mixed with molten phosphorus slag $\left(\mathrm{Ca}_{3} \mathrm{Si}_{2} \mathrm{O}_{7}\right)$. As shown in Fig. 4, small amounts of solid-phase $\mathrm{CaF}_{2}$ underwent transformation at $1000^{\circ} \mathrm{C}$ into slag-phase $\mathrm{CaF}_{2}(0.11 \%), \mathrm{NaF}(0.03 \%)$, and $\mathrm{ZnF}_{2}$ $(0.02 \%)$. The possible reactions can be described by Eqs. (11)-(12). However, reaction (12) did not occur because the Gibbs free energy estimated by Factsage 


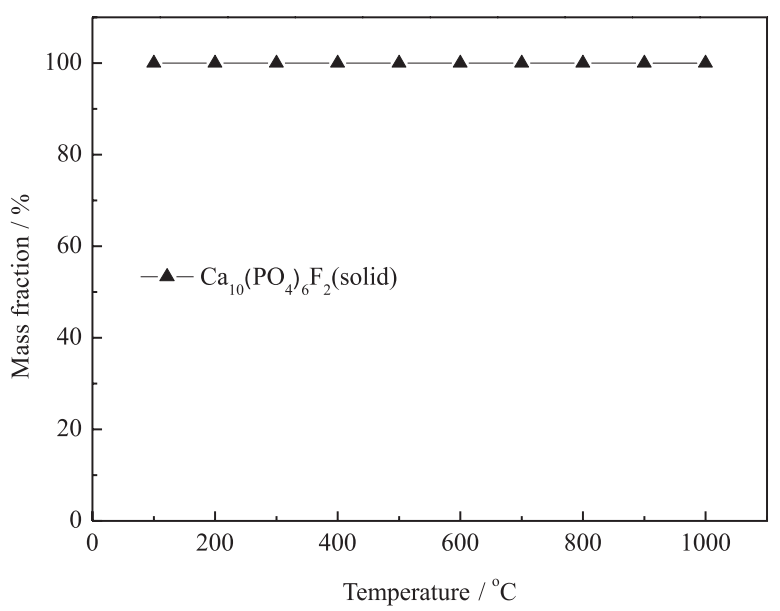

Fig. 3. Distribution of phosphorus products in different phases during the heating process.

calculation at $\left(1000^{\circ} \mathrm{C}, 101325 \mathrm{~Pa}\right)$ was above zero $(\Delta \mathrm{G}>0)$. Thus, the formation mechanism of $\mathrm{ZnF}_{2}$ may be more complex.

$$
\begin{gathered}
\mathrm{Ca}_{10}\left(\mathrm{PO}_{4}\right)_{6} \mathrm{~F}_{2}+15 \mathrm{C}+6 \mathrm{SiO}_{2} \rightarrow \\
3 \mathrm{P}_{2}+15 \mathrm{CO}+3 \mathrm{Ca}_{3} \mathrm{Si}_{2} \mathrm{O}_{7}+\mathrm{CaF}_{2} \\
6 \mathrm{CaF}_{2}+7 \mathrm{SiO}_{2} \rightarrow 3 \mathrm{SiF}_{4}+2 \mathrm{Ca}_{3} \mathrm{Si}_{2} \mathrm{O}_{7} \\
\mathrm{CaF}_{2}+\mathrm{Na}_{2} \mathrm{O} \rightarrow 2 \mathrm{NaF}+\mathrm{CaO} \\
\mathrm{CaF}_{2}+\mathrm{ZnO} \rightarrow \mathrm{ZnF}_{2}+\mathrm{CaO}
\end{gathered}
$$

\section{Migration and Transformation of Arsenic}

Fig. 5 shows the distribution of As-containing species in different phases during the preparation of sintered brick. The migration and transformation of As during the heating process can be divided into three stages. During the first stage, As existed in phosphorus

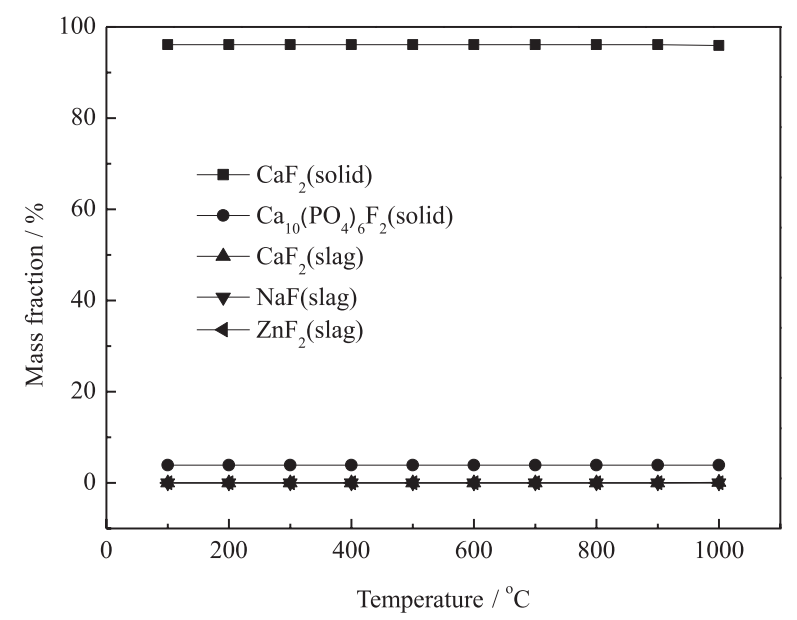

Fig. 4. Distribution of fluorine products in different phases during the heating process. slag as solid phase $\mathrm{Ca}_{3}\left(\mathrm{AsO}_{4}\right)_{2}$ from 100 to $700^{\circ} \mathrm{C}$. This was caused by the high and low contents of $\mathrm{CaO}$ and As in phosphorus slag. Besides, the high stability of formed $\mathrm{Ca}_{3}\left(\mathrm{AsO}_{4}\right)_{2}$ during the heating process effectively suppressed the release of As when yellow phosphorus slag was used as raw material of sintering brick [28]. The predicted result agreed well with previously reported studies [29], confirming that $\mathrm{CaO}$ was used as an additive to sinter and solidify As-containing waste residue according to Eq. (13). In fact, $\Delta \mathrm{G}$ of Eq. (13) was always below zero at temperatures from $100-1000^{\circ} \mathrm{C}$, as estimated by the reaction module of FactSage. This suggested that Eq. (13) can spontaneously occur toward the right side in the entire calcination temperature region.

As the calcination temperature increased from $700^{\circ} \mathrm{C}$ to $900^{\circ} \mathrm{C}$ (second stage), the content of solid phase $\mathrm{Ca}_{3}\left(\mathrm{AsO}_{4}\right)_{2}$ decreased from $99.88 \%$ to 0 , and the content of gas phase $\mathrm{AsF}_{3}$ rose from $0.12 \%$ to $100 \%$. This indicated that the solid phase $\mathrm{Ca}_{3}\left(\mathrm{AsO}_{4}\right)_{2}$ fully transformed at $900^{\circ} \mathrm{C}$. The formation of gas phase $\mathrm{AsF}_{3}$ may be due to complex chemical reactions occurring between $\mathrm{Ca}_{3}\left(\mathrm{AsO}_{4}\right)_{2}$ and $\mathrm{F}$-containing solid from phosphorus slag. Liu et al. [30] found that As leaching content in yellow phosphorus slag by leaching experiment decreased as calcination temperature rose from $650-900^{\circ} \mathrm{C}$. This indirectly indicated that As-containing gases were released from phosphorus slag during the heating process. Wang et al. [31] suggested that $\mathrm{Ca}_{3}\left(\mathrm{AsO}_{4}\right)_{2}$ could not be thermally decomposed, but might be transformed into unstable phase transformation product $\left(\mathrm{CaO} \cdot \mathrm{As}_{4} \mathrm{O}_{6} \cdot \mathrm{As}_{2} \mathrm{O}_{3}\right)$ from $800-1000^{\circ} \mathrm{C}$. It can be seen that $\mathrm{CaO} \cdot \mathrm{As}_{4} \mathrm{O}_{6} \cdot \mathrm{As}_{2} \mathrm{O}_{3}$ may be involved in the complex solid-phase reaction at high temperatures, resulting in released As-containing gaseous pollutants.

During the third stage from 900 to $1000^{\circ} \mathrm{C}$, the As state of phosphorus slag existed as gas phase $\mathrm{AsF}_{3}$ and slag phase $\mathrm{As}_{2} \mathrm{O}_{3}$. The content of $\mathrm{AsF}_{3}$ decreased from $100 \%$ to $46.86 \%$ and that of $\mathrm{As}_{2} \mathrm{O}_{3}$

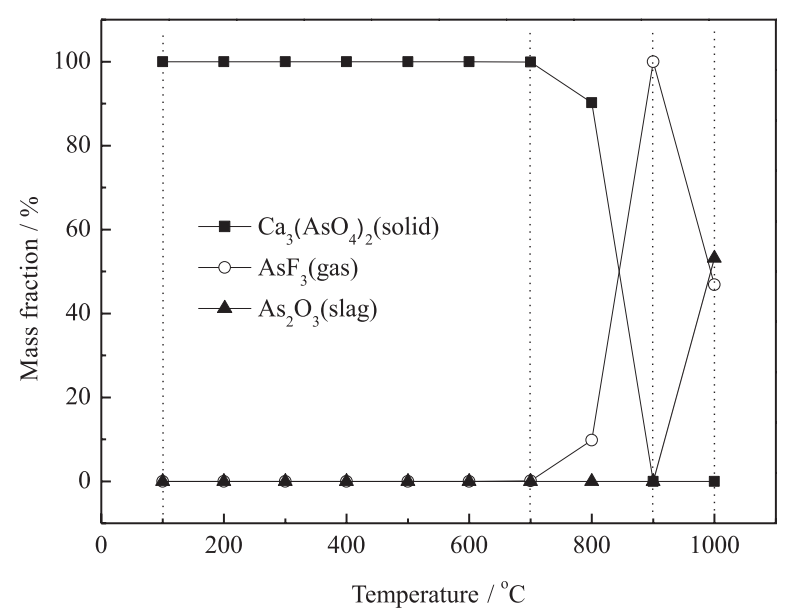

Fig. 5. Distribution of arsenic products in different phases during the heating process. 
increased from 0 to $53.14 \%$. Zhang et al. [32] reported the release characteristics of arsenic during the sintering of arsenic-containing waste residues, suggesting that $\mathrm{CaMgSi} \mathrm{O}_{6}\left(\mathrm{CaO} \cdot \mathrm{MgO} \cdot 2 \mathrm{SiO}_{2}\right)$ and $\mathrm{As}_{2} \mathrm{O}_{3}$ are products of solid-phase reaction at temperatures above $1000^{\circ} \mathrm{C}$. Here, the chemical reactions between $\mathrm{Ca}_{3}\left(\mathrm{AsO}_{4}\right)_{2}$ and raw materials composition of sintered brick $\left(\mathrm{SiO}_{2}\right.$, $\mathrm{Al}_{2} \mathrm{O}_{3}, \mathrm{Na}_{2} \mathrm{O}, \mathrm{K}_{2} \mathrm{O}, \mathrm{MgO}, \mathrm{Fe}_{2} \mathrm{O}_{3}$, among others) were calculated using the reaction module of FactSage. The calculation results showed that Eqs. (14) and (15) could spontaneously occur forward at $1000-1100^{\circ} \mathrm{C}$ and $101325 \mathrm{~Pa}$. Therefore, the formation of slag phase $\mathrm{As}_{2} \mathrm{O}_{3}$ may be due to both solid phase reactions (Eqs. (14) and (15)). On the other hand, the phase transformation product $\left(\mathrm{CaO} \cdot \mathrm{As}_{4} \mathrm{O}_{6} \cdot \mathrm{As}_{2} \mathrm{O}_{3}\right)$ of $\mathrm{Ca}_{3}\left(\mathrm{AsO}_{4}\right)_{2}$ in the solid phase reactions could not be excluded.

$$
\begin{gathered}
3 \mathrm{CaO}+\mathrm{As}_{2} \mathrm{O}_{3}+\mathrm{O}_{2} \rightarrow \mathrm{Ca}_{3}\left(\mathrm{AsO}_{4}\right)_{2} \\
\mathrm{Ca}_{3}\left(\mathrm{AsO}_{4}\right)_{2}+6 \mathrm{SiO}_{2}+3 \mathrm{MgO} \rightarrow \\
3 \mathrm{CaMgSi}_{2} \mathrm{O}_{6}+\mathrm{As}_{2} \mathrm{O}_{3}+\mathrm{O}_{2}(\mathrm{~g}) \\
\mathrm{Ca}_{3}\left(\mathrm{AsO}_{4}\right)_{2}+6 \mathrm{SiO}_{2}+3 \mathrm{Al}_{2} \mathrm{O}_{3} \rightarrow \\
3 \mathrm{CaAl}_{2} \mathrm{Si}_{2} \mathrm{O}_{8}+\mathrm{As}_{2} \mathrm{O}_{3}+\mathrm{O}_{2}(\mathrm{~g})
\end{gathered}
$$

\section{Conclusions}

The migration and transformation of the elements $\mathrm{S}$, $\mathrm{P}, \mathrm{F}$, and As were calculated and analyzed during the calcination process of sintered brick preparation from water-quenched yellow phosphorus slag. Particular attention was given to the release of S-, P-, F-, and As-containing gaseous pollutants. The following conclusions could be drawn:

1) At calcination temperatures up to $900^{\circ} \mathrm{C}$, the gas phase $\mathrm{SO}_{2}$ and $\mathrm{SO}_{3}$ started to be released, and S-containing gaseous pollutants increased as temperature rose. The formation of gas-phase $\mathrm{SO}_{2}$ and $\mathrm{SO}_{3}$ was due to the solid phase reaction between $\mathrm{CaSO}_{4}$ and $\mathrm{SiO}_{2}$ (or $\mathrm{Al}_{2} \mathrm{O}_{3}$ ).

2) The P-containing gaseous pollutants had not been released during the entire calcination temperature region $\left(100-1000^{\circ} \mathrm{C}\right)$, and all $\mathrm{P}$ existed as solid phase $\mathrm{Ca}_{10}\left(\mathrm{PO}_{4}\right)_{6} \mathrm{~F}_{2}$.

3) The F- and As-containing gaseous pollutants existed as $\mathrm{AsF}_{3}$ above $700^{\circ} \mathrm{C}$. However, the release rule of $\mathrm{AsF}_{3}$ was different from that of S-containing gaseous pollutants. The formation of gas phase $\mathrm{AsF}_{3}$ may be due to the elevated temperature reaction between $\mathrm{Ca}_{3}\left(\mathrm{AsO}_{4}\right)_{2}$ and $\mathrm{F}$-containing solid.

\section{Acknowledgments}

This work was fnancially supported by the National Natural Science Foundation of China (No. 51768074), the Foundation for High-level Talents of Chongqing University of Art and Sciences (No. 2017RCH07) and the Scientifc Research Foundation of Yunnan Agricultural University (No. A2002350).

\section{Conflict of Interest}

The authors declare no conflict of interest.

\section{Referfences}

1. SU Y., LI G.B., XIA, J.P. Kinetic study of Fe removal from precipitated silica prepared from yellow phosphorus slag. Can. J. Chem. Eng. 87, 610, 2009.

2. QIN Y.S., WANG Z.H., HUANG X.F., MA L.P., Jiang M., Zhou T. Utilization of melting yellow phosphor furnace slag. Chem. Ind. Eng. Prog. 31, 2319, 2012 [In Chinese].

3. ALLAHVERDI A., PILEHVAR S., MAHINROOSTA $\mathrm{M}$. Influence of curing conditions on the mechanical and physical properties of chemically-activated phosphorous slag cement. Powder Technol. 288, 132, 2016.

4. WANG H.L., WANG J.J., SUN X.Y., JIN W.L. Improving performance of recycled aggregate concrete with superfine pozzolanic powders. J. Cent. South Univ. 20, 3715, 2013.

5. HE D.L., DONG F.Q., LUO Y.J., HUANG L.L., ZHANG B.S. Preparation of spherical calcium carbonate from phosphorus slag. J. Chin. Ceram. Soc. 38, 1268, 2010 [In Chinese].

6. LIU L.B., ZHANG Y.S., ZHAO D.M., ZHANG L.H., TANG K.J. Preparation of calcium carbonate whisker with the yellow phosphorus slag under hydrothermal conditions. J. Synth. Cryst. 40, 801, 2011 [In Chinese].

7. KARSHIGINA Z., ABISHEVA Z., BOCHEVSKAYA Y., AKCIL A., SARGELOVA E. Recovery of rare earth metals and precipitated silicon dioxide from phosphorus slag. Miner. Eng. 77, 159, 2015.

8. ZHOU J., SHU Z., HU X.H., WANG Y.X. Direct utilization of liquid slag from phosphorus-smelting furnace to prepare cast stone as decorative building material. Constr. Build. Mater. 24, 811, 2010

9. LEBEDEVA O.E., DUBOVICHENKO A.E., KOTSUBINSKAYA O. I., SARMURZINA A.G. Preparation of porous glasses from phosphorus slag. J. Non-Cryst. Solids 277, 10, 2000.

10. LIU H.P., MA L.P., HUANG X.F., TANG J.X., YANG J., YANG J. Effect of different amounts of slag on the crystallization behavior of glass-ceramics produced by natural cooling yellow phosphorus slag. RSC Adv., 6, 87696, 2016.

11. DING N., XIA J.P., ZHANG Z.S. A study on preparation of ceramics timber of low temperature which uses plant remainder and the phosphorus dreg of industry abolishes. Sci. Technol. Chem. Ind. 17, 22, 2009 [In Chinese].

12. CAO J.X., CHEN Q.L., LIN Q. Application of phosphorus slag in sintered brick. New Wall Mater. Constr. 7, 11, 2002 [In Chinese].

13. HUANG Q.F., YANG Y.F., WANG Q. Potential for serious environmental threats from uncontrolled co-processing of wastes in cement kilns. Environ. Sci. Technol. 46, 13031, 2012.

14. BALE C.W., BÉLISLE E., CHARTRAND P., DECTEROV S.A., ERIKSSON G., HACK K., JUNG I.H., KANG Y.B., MELANCON J., PELTON A.D., ROBELIN C., PETERSEN S. FactSage thermochemical software and databases-recent developments. Calphad 33, 295, 2009. 
15. BALE C.W., BÉLISLE E., CHARTRAND P., DECTEROV S.A., ERIKSSON G., GHERIBI, A.E., HACK K., JUNG I.H., KANG Y.B., MELANCON J., PELTON A.D., PETERSEN S., ROBELIN C., SANGSTER J., SPENCER P., VAN ENDE M.A. FactSage thermochemical software and databases, 2010-2016. Calphad 54, 35, 2016.

16. YOSHIIE R., TAYA Y., ICHIYANAGI T., UEKI Y., NARUSE I. Emissions of particles and trace elements from coal gasification. Fuel 108, 67, 2013.

17. WANG Z.H., JIANG M., NING P., XIE G. Thermodynamic modeling and gaseous pollution prediction of the yellow phosphorus production. Ind. Eng. Chem. Res. 50, 12194, 2011.

18. YAN B., MA L.P., MA J., ZI Z.C., YAN X.D. Mechanism analysis of $\mathrm{Ca}, \mathrm{S}$ transformation in phosphogypsum decomposition with Fe catalyst. Ind. Eng. Chem. Res. 53, 7648, 2014.

19. WU D.Y., WANG Y.H., WANG Y., LI S., WEI, X.L. Release of alkali metals during co-firing biomass and coal. Renew. Energ. 96, 91, 2016.

20. LIU H.P., MA L.P., HUANG X.F., YANG J., TANG J.X., YANG J., LI J.D., JIANG M. Phase transformation of glass-ceramics produced by naturally cooled yellow phosphorus slag during calcination. J. Alloys Compd. 712, 510, 2017.

21. TIAN H.J., GUO Q.J., CHANG J. Research on the kinetic mechanism of thermal decomposition of $\mathrm{CaSO}_{4}$ in nitrogen atmosphere. Chem. React. Eng. Technol. 24, 529, 2008.

22. YAN Z.Q., WANG Z., LIU H., TU Y.J., YANG W., ZENG H.C., QIU, J.R. Decomposition and solid reactions of calcium sulfate doped with $\mathrm{SiO}_{2}, \mathrm{Fe}_{2} \mathrm{O}_{3}$ and $\mathrm{Al}_{2} \mathrm{O}_{3}$. J. Anal. Appl. Pyrolysis 113, 491, 2015.

23. BEN C.A., ROGEZ J., JEMAL M., MATHIEU J.C. Dissolution de l'hydroxyapatite et du phosphate tricalcique $\beta$ dans les solutions d'acide nitrique. J. Therm. Anal. Calorim. 63, 689, 2001.
24. EL ASRI S., LAGHZIZIL A., ALAOUI A., SAOIABI A., M'HAMDI R., EL ABBASSI K., HAKAM A. Structure and thermal behaviors of Moroccan phosphate rock (Bengurir). J. Therm. Anal. Calorim. 95, 15, 2009.

25. YANG J., CHEN J.J., LIU H.Y., LIU D.J. Enhanced effect of aluminum impurity on solid state carbonthermal reduction of fluorapatite. J. Sichuan Univ. (Eng. Sci. Ed.) 47, 186, 2015 [In Chinese].

26. LIU Y.C., LI Q.X., QIU Z.Z., LIU Y.C. Mechanisms $\mathrm{SiO}_{2}$ on the fluoraptite by carbothermic reduction reactin in vacuum. Chin. J. Vac. Sci. Technol. 33, 293, 2013. [In Chinese].

27. SUN Z.L., DU J.X. Furnace-process Yellow Phosphorus. Metallurgical Industry Press: Beijing, China, 2010 [In China].

28. WANG X.R., NONG Z.X., WANG Q. Structural changes in mineral phases and environmental release behavior of arsenic during sintering of arsenic-containing waste. Environ. Sci. 33, 4412, 2012 [In Chinese].

29. ZHANG J., WANG X.R., ZHANG Z.Q., NONG Z.X., LIU F., HE J., YU H.J. Effects of different additives on environmental release behavior of arsenic during sintering of arsenic-containing waste. J. Northwest A \& F Univ. (Nat. Sci. Ed.) 41, 91, 2013 [In Chinese].

30. LIU H.P., HUANG X.F., MA L.P., JIANG M., LI G.B., CHEN D.L. Transformation behavior of harmful component in yellow phosphorus slag for preparation of glass-ceramics. Trans. Mater. Heat Treat. 37, 227, 2016 [In Chinese].

31. WANG W.S., ZHOU C.T., YANG D.Y., LI Y.Z. Fixation of arsenic in industrial calcium arsenate sludge at moderate temperature. Nonferrous Met. 33, 61, 1981 [In Chinese].

32. ZHANG J., WANG X.R., CHEN Y.M., ZHAO C.X., JIN J., PENG Y. Impacts of $\mathrm{CaO}$ on species and release characteristics of arsenic during sintering of arseniccontaining waste residue. Res. Environ. Sci. 28, 796, 2015 [In Chinese]. 
